\title{
Coronavirus: 10 Things That Family Businesses Can Do Now
}

\author{
David Deeds (University of St. Thomas)
}

KEYWORDS: Management, Family Business, financing, crisis management.

Editor's Note: Over the next few weeks we will be publishing articles on familybusiness.org (https://familybusiness.org) and EIX.org to help businesses weather the turmoil caused by COVID19. Visit our home page daily for more articles.

Two weeks ago, it was business as usual for family businesses around the world. But COVID19, the virus that as of March 16 has sickened nearly 175,000 people around the world, is frightening new territory for all of us.

Over the next few weeks familybusiness. org will strive to bring our visitors solid advice to help them get through this difficult time. We will focus on the unique challenges of family-run businesses, who have been forced to close their doors and whose prime customers may be facing quarantines and cash challenges of their own. We expect that smaller companies could see revenue plunge as much as $50 \%$ over the next year.

For this first article, I will share 10 lessons l've learned from teaching entrepreneurs about economic downturns for the past 27 years.

1. It's all about managing your cash. Plan for the next three months or more with substantially reduced revenues.

2. Delay large purchases. This is not the time for capital equipment, expansions or big expenditures.

3. Cut the marketing budget. Unless you have something that will be in demand at this time, don't spend on advertising or marketing. No sense selling when nobody is buying. However, if you can add delivery (see tip \#5), it's worth spending money to spread the word.

4. Figure out who you need. Find ways to keep those key employees, even if it means losing more money because you are continuing to pay salaries. You probably can't keep them all, but make sure you keep

Copyright $(92020$ The Authors. Entrepreneur \& Innovation Exchange is published at EIX.org. This is an open access article under the terms of the Creative Commons Attribution-NoDerivs License, which permits use and distribution in any medium, provided the original work is properly cited and 